\title{
Business Program Participation and Engineering Innovation: An Exploration of Engineering Students' Minors, Certificates, and Concentrations
}

\author{
Ms. Emily Cao, Stanford University \\ Mechanical Engineering student at Stanford University. \\ Dr. Shannon Katherine Gilmartin, Stanford University \\ Dr. Qu Jin, Stanford University
}

Qu Jin is a postdoctoral scholar in the Designing Education Lab at Stanford University. She earned her $\mathrm{Ph} . D$. degree in Engineering Education from Purdue University in 2013, M.S. degree in Biomedical Engineering from Purdue University in 2009, and B.S. degree in Material Science and Engineering from Tsinghua University in China in 2007. Her research interests focus on educational studies that can help improve teaching, learning, and educational policy decision makings using both quantitative and qualitative research methods. Her current research project in National Center for Engineering Pathways to Innovation (Epicenter) focuses on measuring engineering students' entrepreneurial interests and related individual characteristics. Her Ph.D. dissertation involved using statistical modeling methods to explain and predict engineering students' success outcomes, such as retention, academic performance, and graduation.

\section{Ms. Carolin Christin Dungs, Stanford University \\ Dr. Sheri Sheppard, Stanford University}

Sheri D. Sheppard, Ph.D., P.E., is professor of Mechanical Engineering at Stanford University. Besides teaching both undergraduate and graduate design and education related classes at Stanford University, she conducts research on engineering education and work-practices, and applied finite element analysis. From 1999-2008 she served as a Senior Scholar at the Carnegie Foundation for the Advancement of Teaching, leading the Foundation's engineering study (as reported in Educating Engineers: Designing for the Future of the Field). In addition, in 2011 Dr. Sheppard was named as co-PI of a national NSF innovation center (Epicenter), and leads an NSF program at Stanford on summer research experiences for high school teachers. Her industry experiences includes engineering positions at Detroit's "Big Three:" Ford Motor Company, General Motors Corporation, and Chrysler Corporation.

At Stanford she has served a chair of the faculty senate, and recently served as Associate Vice Provost for Graduate Education. 


\section{Business program participation and engineering innovation: An exploration of engineering students' minors, certificates, and concentrations}

\section{Introduction}

One of the main goals of engineering education is to foster a new generation of engineers, leaders, and innovators to be adept and well equipped for a fast-paced, technologically advanced workforce. Following suit, engineering schools (and college campuses more broadly) are offering a wealth of new curricular and co-curricular programs to augment students' learning within and in conjunction with their major fields of study. Students can pursue different concentrations within each major, as well as pursue minors and certificates. Yet little is known about such intricacies of engineering students' studies. The overarching objective of this research is to investigate this more granular programmatic space. By studying minors, certificates, and concentrations, we can develop a deeper, broader understanding of the educational environments available to engineering students, the characteristics of students who are most apt to participate in them, and the impact of this environment on student development.

For this paper, we focus on engineering students enrolled in business-related concentrations, minors, or certificates, and explore the similarities and differences between business-interested engineering students and their peers. Technological innovation and entrepreneurship are becoming increasingly important for preparing students for the workforce, and many engineering schools are introducing entrepreneurship and business education into coursework. What do these new programmatic opportunities look like? Which type of student is most likely to take advantage of these new opportunities? What are possible outcomes of these opportunities? In an effort to understand the effectiveness of Innovation and Entrepreneurship (I\&E) learning environments in engineering courses and programs, it is valuable to assess the characteristics and career goals of engineering students who pursue them.

\section{Research Questions}

The primary research questions for this study are:

1. What are characteristics of engineering students who are pursuing business minors, concentrations, and certificates?

2. Are these students more likely to be involved in entrepreneurship-related and other extraand co-curricular activities than are other engineering students?

3. Do these students have higher (or lower) innovation self-efficacy than do other engineering students?

4. Is there a difference in career goals between these students and their peers?

In this study, we are exploring the relationships between engineering students' participation in business programs and their innovation self-efficacy, leadership and entrepreneurship experiences, and innovation-related career goals. Based on study findings, we can begin to explore the possible impact of these new types of educational opportunities on student outcomes.

\section{Background of the Study}




\section{Entrepreneurship programs for engineers}

Although relatively little is known about the types and impact of minors, certificates, and concentrations in engineering education, there are a handful of previous studies that shine a light on business-related learning opportunities for engineers, usually in the context of entrepreneurship. Over half of all engineering programs provide entrepreneurship learning options for students, and about one-quarter of these are primarily in the form of minors, certificates, and concentrations ${ }^{9}$. Some of these entrepreneurship programs in engineering are jointly administered with schools of business.

Studies have pointed towards a relationship between taking an entrepreneurship related course and "entrepreneurial self-efficacy" ${ }^{3}$. There were disciplinary differences in who participated in these courses, with students in Electrical and Mechanical Engineering more likely to do so than were students in other engineering fields. Interestingly, most engineering students in the sample expected to work for a medium to large sized company rather than start their own firm, regardless of entrepreneurship course participation (still, those who did participate in such coursework had stronger entrepreneurial career interests than did others).

\section{Engineering students and innovation}

Entrepreneurship (and by extension, business) is linked to innovation, although these concepts are not synonymous ${ }^{2,7}$. There is little research linking students' innovativeness to businessrelated learning opportunities, but there are more general studies of innovativeness among engineers. Previous research has shown that first-year engineering students came up with more creative solutions than did seniors, suggesting that innovation capability may decrease during college ${ }^{6}$. In another study, creativity and perceptions of creativity among twenty senior engineering students were explored via interviews and think-aloud protocols ${ }^{5}$. The results showed that students did not see themselves as creative and furthermore avoided expanding their tasks beyond the familiar ones that aligned with their knowledge of their discipline.

Previous research also indicates that engineering students in different disciplines approach "engineering innovation" differently ${ }^{4}$. In this study, students in different majors demonstrated different perspectives on nine aspects of innovation: context, criteria, stakeholder, involvement, teamwork, design process, iteration, knowledge, challenges and personal motivation. The different perspectives could all be linked with their specific knowledge due to their discipline.

Providing a comparative view of both innovation and entrepreneurship, Jin et al. found that engineering students on the whole have lower entrepreneurial intent than do business students ${ }^{7}$. Business students also evaluate themselves more positively than do engineering students on "innovation orientation", which is defined as willingness to partake in innovative behaviors such as "generating creative ideas".

\section{Summary}

While studies have examined entrepreneurship programs for engineers, or innovativeness among engineers, previous research has not looked at business-related program participation among engineers more broadly. Nor has previous research linked this type of participation to not only students' self-concepts around innovation, but also their career goals, and related extracurricular activities. The current study will shine a light on these domains, and begin to address the types of impact that these learning environments might have on engineering student outcomes. 


\section{Methods}

\section{Survey instrument and sample}

The study draws from data collected as part of the Engineering Majors Survey (EMS), a national survey administered in 2015 to engineering students across 27 U.S. colleges and universities. The EMS was conducted under the umbrella of the Fostering Innovative Generations Studies (FIGS), which collectively represent the research branch of the National Center for Engineering Pathways to Innovation, or Epicenter. A total of 7,197 students responded to the EMS, 6,187 of who were self-reported "juniors" or "seniors" (in keeping with the target sample). The sample for the present study is composed of all 7,197 EMS survey respondents.

The EMS was designed to be a 10-minute online questionnaire about students' attitudes, experiences, and goals relating to innovation, entrepreneurship, and engineering. The survey was grounded in Social Cognitive Career Theory (SCCT) ${ }^{8}$, which postulates that career goals are a function of interests, self-efficacy, outcome expectations for performing certain tasks, and learning experiences, as well as background and contextual characteristics (e.g., students' gender, race/ethnicity, and major). Situating the analyses in the present study in this model, we are exploring the specific relationships between participation in a business minor, certificate, or concentration - a "learning experience"- and other SCCT constructs: Innovation Self-Efficacy (ISE) and Career Goals: Innovation Work (CGIW).

The EMS institutional sample represents a stratified quasi-random sample of $\sim 350$ U.S. engineering schools. Schools were stratified on the basis of: 1) research university or nonresearch university, 2) size of engineering school as measured by number of engineering degrees awarded, and 3) presence of an undergraduate business major on campus. This resulted in a $2 \times 2 \times 2$ scheme. Institutions within each stratification "cell" were "quasi" randomly sampled in that schools were flagged as "Epicenter affiliated" or "not Epicenter affiliated", and, where possible, roughly equal numbers were randomly selected from each group (Epicenter affiliation denoted participation in the University Innovation Fellows or Pathways to Innovation programs, see http://epicenter.stanford.edu/). More details about institutional sampling will be made available in an upcoming technical report for the EMS project.

Students were incentivized to participate in the survey via a random drawing for one of 200 \$25.00 Amazon gift cards. The 27 participating institutions administered the survey to their students using a survey link provided by the research team. Schools emailed up to two reminders to students after the initial invitation. Most schools administered the survey in February/March 2015; a very small number followed in April/May. The survey was open for roughly three weeks.

\section{Analyses}

Background questions on the EMS concerning field of study indicate respondents were pursuing one of 39 unique engineering majors (or, for a small proportion of respondents, two engineering majors, or one engineering and one non-engineering major). A total of 2,500 respondents were pursuing concentrations within those majors. Respondents were also asked to write-in any minors or certificates pursued in order to generate a complete picture of students' academic 
programs. Approximately $36 \%$ reported pursuing a concentration, $27 \%$ reported pursuing a minor, and $5 \%$ reported pursuing a certificate.

Among these certificates, minors, and concentrations, we identified those that are related to business. A total of 486 engineering students ( $6.8 \%$ of the sample) were participating in business concentrations, minors, or certificates. Table 1 summarizes numbers and percentages of "business-flagged" and non-flagged students by gender and by race/ethnicity.

Table 1. Demographic characteristics of participants

\begin{tabular}{|l|c|c|c|c|}
\hline \multirow{2}{*}{} & \multicolumn{3}{|c|}{ Business Flagged } & \multicolumn{2}{|c|}{ Not Flagged } \\
\cline { 2 - 5 } & $\mathrm{N}$ & $\%$ & $\mathrm{~N}$ & $\%$ \\
\hline All Participants & 485 & $6.8 \%$ & 6712 & $93.3 \%$ \\
\hline Sex & 297 & $69.9 \%$ & 3993 & $69.5 \%$ \\
\hline Male & 128 & $30.1 \%$ & 1753 & $30.5 \%$ \\
\hline Female & 425 & $100 \%$ & 4756 & $100 \%$ \\
\hline Valid Total & 0 & $0 \%$ & 21 & $0.4 \%$ \\
\hline Race/Ethnicity & 57 & $13.6 \%$ & 765 & $13.6 \%$ \\
\hline American Indian or Alaska Native & 12 & $2.9 \%$ & 175 & $3.1 \%$ \\
\hline Asian or Asian American & 19 & $4.5 \%$ & 346 & $6.2 \%$ \\
\hline African American & 0 & $0 \%$ & 8 & $0.1 \%$ \\
\hline Hispanic or Latino & 315 & $75.2 \%$ & 3939 & $70.2 \%$ \\
\hline Native Hawaiian or Pacific Islander & 1 & $0.2 \%$ & 10 & $0.2 \%$ \\
\hline White & 15 & $3.6 \%$ & 344 & $6.1 \%$ \\
\hline Other & 419 & $100 \%$ & 5608 & $100 \%$ \\
\hline Multiracial & \multicolumn{5}{|l|}{} \\
\hline Valid Total & 0
\end{tabular}

Concentrations, minors, and certificates were grouped into the following business-related areas based on write-in popularity: management, entrepreneurship, business administration, business, leadership, economics, finance, enterprise, operations, business analytics, and business technology. The most popular fields of study within the flagged programs are business $(20.2 \%)$, economics $(17.3 \%)$, business administration (14.8\%), and management $(11.3 \%)$, as seen in Figure 1 and Table 2.

Figure 1. Popularity of business-related minors, concentrations, and certificates 


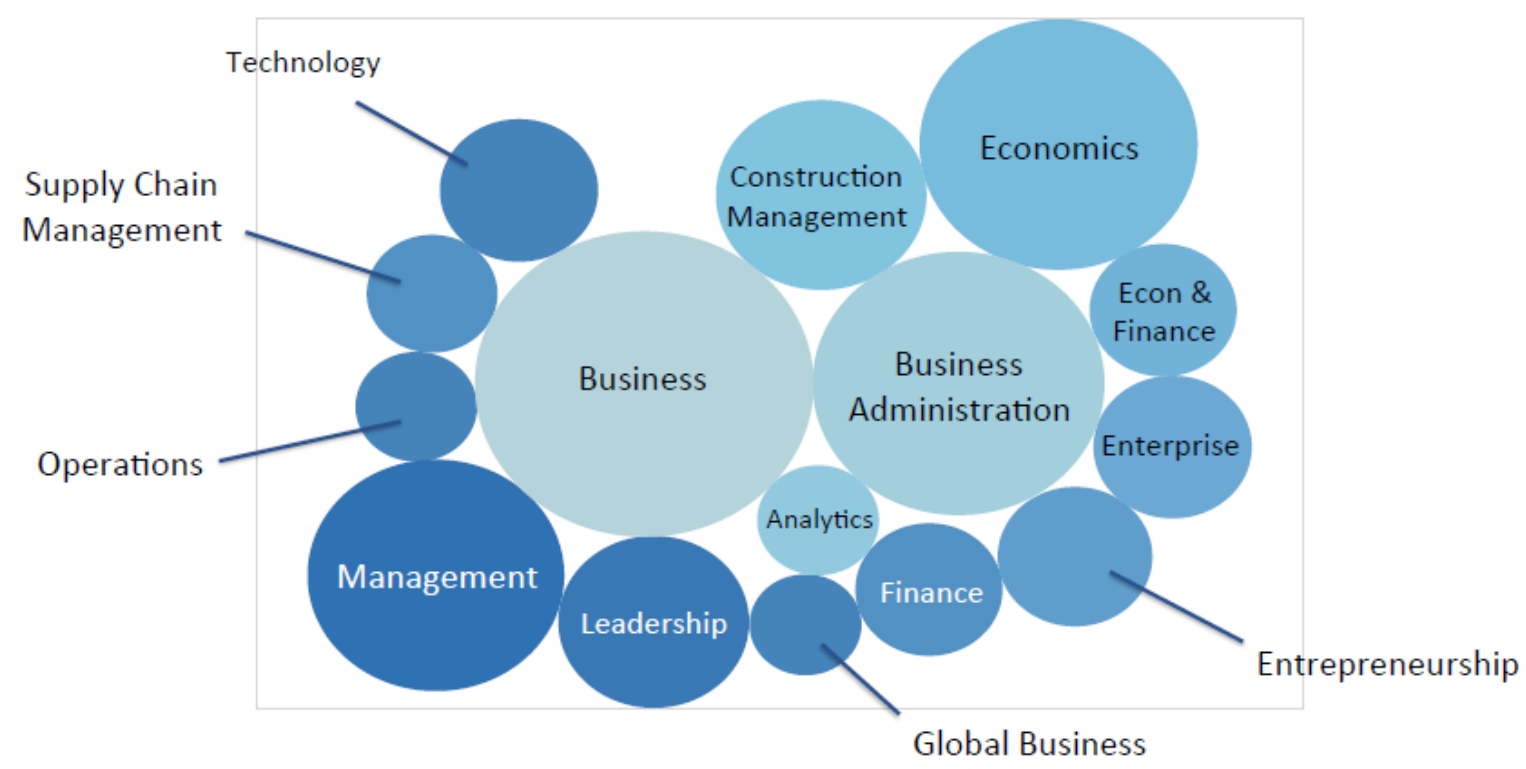

Table 2. Number and percentage of business-flagged students by their business-related minors, concentrations, and certificates

\begin{tabular}{|l|l|l|}
\hline Grouping & $\mathrm{N}$ & $\%$ \\
\hline Business & 98 & $20.2 \%$ \\
\hline Economics & 84 & $17.3 \%$ \\
\hline Business Administration & 72 & $14.8 \%$ \\
\hline Management & 55 & $11.3 \%$ \\
\hline Construction Management & 36 & $7.4 \%$ \\
\hline Leadership & 29 & $6.0 \%$ \\
\hline Technology & 19 & $3.9 \%$ \\
\hline Enterprise & 19 & $3.9 \%$ \\
\hline Entrepreneurship & 18 & $3.7 \%$ \\
\hline Finance & 16 & $3.3 \%$ \\
\hline Supply Chain Management & 12 & $2.5 \%$ \\
\hline Operations & 10 & $2.1 \%$ \\
\hline Business Analytics & 10 & $2.1 \%$ \\
\hline Global Business & 8 & $1.6 \%$ \\
\hline
\end{tabular}


In order to conduct between-group comparisons for this study, IBM SPSS and Microsoft Excel were used for statistical testing. Chi-square tests were conducted to test if flagged students were more likely to be involved in entrepreneurship related and other extra- and co-curricular activities than were other engineering students. T-tests were used to test if flagged students had higher scores in Innovation Self-Efficacy and Career Goals-Innovative Work.

\section{Results}

\section{What are characteristics of engineering students pursuing business minors, concentrations, and certificates?}

We first looked into the distribution of business flagged and non-flagged students as grouped by their field of study (Table 3). Differences in the distribution were observed. Civil Engineering and Industrial Engineering students are more likely to pursue business minors, concentrations, and certificates. Students from Aerospace, Chemical, Electrical, Mechanical, and Other engineering majors are less likely to pursue business minors, concentrations, and certificates. The difference was significant according a Chi-square test $(\mathrm{p}<.001)$.

We then compared business-flagged and non-flagged students on their institutional characteristics. As shown in Table 3, the percentages of business flagged and non-flagged students are consistent across different types of institutions (research vs. non-research; with undergraduate business major vs. without undergraduate business major; large vs. small engineering programs) $(\mathrm{p}>0.05)$.

Table 3. Number and percentage of business flagged and non-flagged students by their major and institutional characteristics

\begin{tabular}{|c|c|c|c|c|}
\hline & \multicolumn{2}{|c|}{ Business Flagged } & \multicolumn{2}{|c|}{ Not Flagged } \\
\hline & $\mathrm{N}$ & $\%$ & $\mathrm{~N}$ & $\%$ \\
\hline \multicolumn{5}{|l|}{ Major } \\
\hline Aerospace Engineering & 10 & $2 \%$ & 305 & $5 \%$ \\
\hline Chemical Engineering & 27 & $6 \%$ & 569 & $8 \%$ \\
\hline Civil Engineering & 81 & $17 \%$ & 730 & $11 \%$ \\
\hline Electrical Engineering & 43 & $9 \%$ & 1324 & $20 \%$ \\
\hline Industrial Engineering & 114 & $24 \%$ & 214 & $3 \%$ \\
\hline Materials Engineering & 13 & $3 \%$ & 189 & $3 \%$ \\
\hline Mechanical Engineering & 97 & $20 \%$ & 1737 & $26 \%$ \\
\hline Other Engineering & 100 & $21 \%$ & 1636 & $24 \%$ \\
\hline \multicolumn{5}{|l|}{ Institutional Characteristics } \\
\hline Research Institutions & 384 & $79.2 \%$ & 5137 & $76.5 \%$ \\
\hline Non-Research Institutions & 101 & $20.8 \%$ & 1575 & $23.5 \%$ \\
\hline $\begin{array}{l}\text { Institutions With Undergraduate Business } \\
\text { Major }\end{array}$ & 343 & $70.7 \%$ & 4729 & $70.5 \%$ \\
\hline $\begin{array}{l}\text { Institutions Without Undergraduate } \\
\text { Business Major }\end{array}$ & 142 & $29.3 \%$ & 1983 & $29.5 \%$ \\
\hline
\end{tabular}




\begin{tabular}{|l|l|l|l|l|}
\hline Large engineering schools & 343 & $70.7 \%$ & 4538 & $67.6 \%$ \\
\hline Small engineering schools & 142 & $29.3 \%$ & 2174 & $32.4 \%$ \\
\hline
\end{tabular}

2. $\quad$ Are these students more likely to be involved in entrepreneurship related and other extraand co-curricular activities than are other engineering students?

As summarized in Table 4, students pursuing business minors, concentrations, and certificates are significantly more likely to have led a student organization, have started/co-founded a student club or other student group on campus, or have started/co-founded their own for-profit or nonprofit organization during undergraduate years.

Table 4. Leading or starting clubs and organizations among business flagged and non-flagged students

\begin{tabular}{|c|c|c|c|c|c|}
\hline \multirow[b]{2}{*}{$\begin{array}{l}\text { Which of the following } \\
\text { you have done during } \\
\text { your undergraduate } \\
\text { years: }\end{array}$} & \multicolumn{2}{|c|}{ Business Flagged } & \multicolumn{2}{|l|}{ Not Flagged } & \multirow[b]{2}{*}{$\begin{array}{c}\mathrm{p}- \\
\text { value }\end{array}$} \\
\hline & $\begin{array}{l}\text { Number of students } \\
\text { marked the } \\
\text { experience (out of } \\
485 \text { ) }\end{array}$ & $\%$ & $\begin{array}{l}\text { Number of students } \\
\text { marked the } \\
\text { experience (out of } \\
6712 \text { ) }\end{array}$ & $\%$ & \\
\hline $\begin{array}{l}\text { Led a student } \\
\text { organization }\end{array}$ & 171 & $36.9 \%$ & 1577 & $25.1 \%$ & $\begin{array}{c}< \\
.001\end{array}$ \\
\hline $\begin{array}{l}\text { Started or co-founded a } \\
\text { student club or other } \\
\text { student group on campus }\end{array}$ & 56 & $12.1 \%$ & 526 & $8.4 \%$ & 0.008 \\
\hline $\begin{array}{l}\text { Started or co-founded } \\
\text { your own for-profit or } \\
\text { non-profit organization }\end{array}$ & 27 & $5.8 \%$ & 143 & $2.3 \%$ & $\begin{array}{c}< \\
.001\end{array}$ \\
\hline
\end{tabular}

As summarized in Table 5, students pursuing business minors, concentrations, and certificates are significantly more likely to have participated in a business or entrepreneurship club, in a community service-based club, in other student clubs or groups in engineering, or in other student clubs or groups outside of engineering during undergraduate years.

Table 5. Participation in clubs and organizations among business flagged and non-flagged students

\begin{tabular}{|l|c|c|c|c|c|}
\hline \multirow{2}{*}{$\begin{array}{l}\text { Which of the following } \\
\text { you have done during your } \\
\text { undergraduate years: }\end{array}$} & $\begin{array}{l}\text { Number of } \\
\text { students marked } \\
\text { the experience (out } \\
\text { of 485) }\end{array}$ & $\%$ & $\begin{array}{l}\text { Number of } \\
\text { students marked } \\
\text { the experience (out } \\
\text { of 6712) }\end{array}$ & $\%$ & $\begin{array}{l}\mathrm{p} \text { - } \\
\text { value }\end{array}$ \\
\hline $\begin{array}{l}\text { Participated in a business } \\
\text { or entrepreneurship club }\end{array}$ & 89 & $19.2 \%$ & 415 & $6.6 \%$ & $\begin{array}{c}< \\
.001\end{array}$ \\
\hline
\end{tabular}




\begin{tabular}{|l|c|c|c|c|c|}
\hline $\begin{array}{l}\text { Participated in a } \\
\text { community service-based } \\
\text { club }\end{array}$ & 136 & $29.4 \%$ & 1483 & $23.6 \%$ & 0.006 \\
\hline $\begin{array}{l}\text { Participated in other } \\
\text { student clubs or groups in } \\
\text { engineering }\end{array}$ & 230 & $49.7 \%$ & 2733 & $43.4 \%$ & 0.01 \\
\hline $\begin{array}{l}\text { Participated in other } \\
\text { student clubs or groups } \\
\text { outside of engineering }\end{array}$ & 238 & $51.4 \%$ & 2710 & $43.1 \%$ & 0.001 \\
\hline
\end{tabular}

As summarized in Table 6, students pursuing business minors, concentrations, and certificates are significantly more likely to have attended a start-up bootcamp (e.g. Start-up Weekend, 3-Day Startup) or entered a business plan, business model, or elevator pitch competition during undergraduate years.

Table 6. Participation in entrepreneurship activities outside of coursework among business flagged and non-flagged students

\begin{tabular}{|l|c|c|c|c|c|}
\hline \multirow{2}{*}{$\begin{array}{l}\text { Which of the following you } \\
\text { have done during your } \\
\text { undergraduate years: }\end{array}$} & $\begin{array}{l}\text { Business Flagged } \\
\begin{array}{l}\text { Number of students } \\
\text { marked the } \\
\text { experience (out of } \\
485 \text { ) }\end{array}\end{array}$ & $\%$ & $\begin{array}{l}\text { Number of students } \\
\text { marked the experience } \\
\text { (out of 6712) }\end{array}$ & $\%$ & $\begin{array}{l}\text { p- } \\
\text { value }\end{array}$ \\
\hline $\begin{array}{l}\text { Attended a start-up bootcamp } \\
\text { (e.g. Start-up Weekend, 3-Day } \\
\text { Startup) }\end{array}$ & 20 & $4.3 \%$ & 149 & $2.4 \%$ & 0.019 \\
\hline $\begin{array}{l}\text { Entered a business plan, } \\
\text { business model, or elevator } \\
\text { pitch competition }\end{array}$ & & & & & \\
\hline
\end{tabular}

Among the extra- and co-curricular activities we tested, we did not find any difference between flagged and non-flagged students in the following items:

- Participation in a design club

- Participation in a robotics club

- Participation in a design or invention competition

- Participation in a social entrepreneurship/social innovation competition (e.g., the Dell Social Innovation Challenge)

- Usage of a maker space/design or inventors studio/prototyping lab

- Attendance of a career related event or meeting (e.g., a college career fair, a one-on-one meeting with a career counselor) 
- Attendance of a speaker series or related presentations about entrepreneurship and/or innovation

- Attendance of a presentation on a new engineering technology, process, or design (outside of class)

- Living in a residential or dorm-based engineering program/engineering living-learning community

- Living in a residential or dorm-based entrepreneurship or innovation program/entrepreneurship or innovation living learning community

3. Do students participating in business/entrepreneurship minors, certificates, and concentrations have higher Innovation Self-Efficacy?

Innovation Self-Efficacy is measured using a scale with six items asking respondents how confident they are in doing the following tasks.

1. Ask a lot of questions

2. Generate new ideas by observing the world

3. Experiment as a way to understand how things work

4. Actively search for new ideas through experimenting

5. Build a large network of contacts with whom you can interact to get new ideas for new products or services

6. Connect concepts that appear, at first glance, to be unconnected

The scale ranges from 0 (Not Confident) to 4 (Extremely Confident). Exploratory factor analysis results suggest that the six items loaded on one factor. The scale of Innovation Self-Efficacy is reliable with Cronbach's coefficient alpha of 0.83. The score of Innovation Self-Efficacy was calculated by taking the average of the six items.

As summarized in Table 7, our results show that students participating in business minors, certificates, and concentrations have a significantly higher average innovation self-efficacy than do their non-business peers $(\mathrm{p}<0.001)$.

\section{Is there a difference in career goals between these students and their peers?}

The Career Goals-Innovative Work scale is composed of six items asking how important it is for the respondent to be involved in the following job or work activities in the first five years after graduation.

1. Searching out new technologies, processes, techniques, and/or product ideas

2. Generating creative ideas

3. Promoting and championing ideas to others

4. Investigating and securing resources needed to implement new ideas

5. Developing plans and schedules for the implementation of new ideas

6. Selling a product or service in the marketplace

The scale ranges from 0 (Not important) to 4 (Extremely important). Exploratory factor analysis results suggest that the six items loaded on one factor. The scale of Career Goals-Innovative Work is reliable with Cronbach's coefficient alpha of 0.86. The score of Career Goals-Innovative Work was calculated by taking the average of the six items. 
As summarized in Table 7, our results show that students participating in business minors, certificates, and concentrations have a significantly higher score in Career Goals-Innovative Work than do their non-business peers $(\mathrm{p}=0.001)$.

Table 7. Self-efficacy and career goals among business flagged and non-flagged students

\begin{tabular}{|l|c|c|c|c|c|}
\hline \multirow{2}{*}{} & \multicolumn{2}{|c|}{ Business Flagged } & \multicolumn{2}{c|}{ Not Flagged } & \multirow{2}{*}{ p-value } \\
\cline { 2 - 5 } & Mean & SD & Mean & SD & p-val \\
\hline Innovation Self Efficacy & 2.7 & 0.7 & 2.3 & 0.7 & $<.001$ \\
\hline Career Goals-Innovative Work & 2.7 & 0.7 & 2.5 & 0.8 & 0.001 \\
\hline
\end{tabular}

\section{Discussion}

In this study, we explored the characteristics of engineering students pursuing business programs in addition to their engineering majors. Our results show that participation in business minors, concentrations, and certificates is correlated with higher involvement in student organizations, leadership, and innovation self-efficacy and career goals. These students are more likely to have led a student organization, have started/co-founded a student club or other student group on campus, or have started/co-founded their own for-profit or non-profit organization during their undergraduate years. These students are also significantly more likely to have participated in a business or entrepreneurship club, in a community service-based club, and in other student clubs or groups in and outside of engineering during their undergraduate years. They are no more nor less likely than are other engineers to participate in such activities as makers spaces, design clubs, and design competitions, however.

Increased levels of leadership and participation in extracurricular and co-curricular organizations may be attributed to exposure to leadership and management education through business programs. Exposure to business and entrepreneurship programs may also be a factor in the increased innovation self-efficacy of these students. At the same time, higher innovation selfefficacy may characterize students who are drawn to these types of programs, and may help to explain higher rates of participating in, leading, and starting or co-founding student groups and organizations.

These findings expand on those of other studies. Miller et al. examined the entrepreneurial activities of engineering students who participated in the Engineering Entrepreneurs program, a three-course sequence for graduates at North Carolina State University. The research team found significantly higher entrepreneurial activities of the students in their post-graduation career ${ }^{9}$. Miller's uncertainty about why this program fosters entrepreneurship outcomes could be explained by the relationship between the participation of engineering students in business programs and the higher innovation self-efficacy and innovation career goals explored in this paper.

In an effort to develop engineers who are prepared to enter a more global, technologically advanced workforce, many schools are beginning to offer curricular and co-curricular programs in I\&E fields ${ }^{10}$. The findings in this paper suggest that engineering students participating in I\&E programs - business-focused programs in particular - in fact are more inclined than are other 
engineering students to pursue post-graduation careers characterized by a high degree of innovative behaviors. Although the absolute percentage of engineering students enrolled in business-related minors, concentrations, and certificates is small, these findings are suggestive in terms of the potential impact of such programs on student development. In light of the finding that engineers tend to have lower innovation orientation than do business students ${ }^{7}$, the results from this study hint that between-discipline differences may depend on participation in certain types of minors, certificates, and concentrations in engineering.

\section{Limitations}

To compare the flagged and non-flagged groups, we performed Chi-square tests and provided the associated p-values. P-value is often dependent on sample size-small p-value is observed when sample size is large (e.g., more than 1000 participants). The alternative way is to provide effect size, which does not depend on sample size, to evaluate the strength of association. In future studies, we would also report effect sizes for the Chi-square tests and t-tests.

The number of students pursuing concentrations, minors, and certificates is small compared to the total population of engineering students in this study. These business program participants are a self-selected group of students, assumed to already have an interest in business, leadership, management, or entrepreneurship. More work is needed to disentangle self-selection from the effects of participating in business programs.

Future research could examine what common innovation and entrepreneurship learning objectives are found in existing business programs. Integrating these learning objectives into engineering coursework would provide a more comprehensive look at the effects of I\&E on engineering students. Future research could further compare engineering students in business programs at schools with a formal undergraduate business major, versus those at schools without - answering the question "does having a business major on campus intensify/moderate effects of business program participation for engineers?"

\section{Conclusion}

This study provides a first look into the interests and characteristics of engineering students also participating in business programs. Approximately 36\% of the total 7,197 EMS respondents reported pursuing a concentration, $27 \%$ reported pursuing a minor, and $5 \%$ reported pursuing a certificate. A total of 486 engineering students (6.8\% of the sample) were participating in business-related concentrations, minors, or certificates. The most popular fields of study within the flagged programs are business $(20.2 \%)$, economics $(17.3 \%)$, business administration $(14.8 \%)$, and management $(11.3 \%)$.

The average innovation self-efficacy and innovation career goals scores of students enrolled in business and entrepreneurial concentrations, minors, and certificates is significantly higher than the innovation self-efficacy and career goals scores of students not participating in these programs. Business-focused students are also more likely to participate in, lead, and start or cofound organizations than their non-business peers. Further research is needed to investigate why business related courses or activities might have an impact on students' career goals and selfefficacy. 


\section{References}

1. Celis, S., \& Huang-Saad, A. (2015, June). Students Seeking Different Paths to Entrepreneurial Education. Paper presented at ASEE Annual Conference and Exposition, Seattle, Washington. 10.18260/p.24768

2. Duval-Couetil, N., Dyrenfurth, M. (2012, September). Teaching Students to be Innovators: Examining Competencies and Approaches Across Disciplines. International Journal of Innovation Science, 4(3).

3. Duval-Couetil, N., Reed-Rhoads, T., \& Haghighi, S. (2012). Engineering students and entrepreneurship education: Involvement, attitudes and outcomes. International Journal of Engineering Education, 28(2), 425.

4. Fila, N. D., Purzer, S., \& Chakroun, R. (2014, October). Cultures of innovation among chemical, civil, and mechanical engineering students: A qualitative study. In Frontiers in Education Conference (FIE), 2014 IEEE (pp. 1-7). IEEE.

5. Fila, N. D., \& Purzer, S., \& Mathis, P. D. (2014, June), I'm Not the Creative Type: Barriers to Student Creativity within Engineering Innovation Projects Paper presented at 2014 ASEE Annual Conference, Indianapolis, Indiana. https://peer.asee.org/20574

6. Genco, N., Hölttä-Otto, K. \& Seepersad, C. C. (2012). An Experimental Investigation of the Innovation Capabilities of Undergraduate Engineering Students. Journal of Engineering Education, 101: 60-81. doi: 10.1002/j.2168-9830.2012.tb00041.x

7. Jin, Q., \& Gilmartin, S. K., \& Sheppard, S. D., \& Chen, H. L. (2014, June), Comparing Engineering and Business Undergraduate Students' Entrepreneurial Interests and Characteristics Paper presented at 2014 ASEE Annual Conference, Indianapolis, Indiana. https://peer.asee.org/20186

8. Lent, R.W., Brown, S.D., \& Hackett, G. (1994). Toward a unifying social cognitive Theory of career and academic interest, choice, and performance. Journal of Vocational Behavior, 45, 79-122.

9. Miller III, T., Walsh, S., Hollar, S., Rideout, E., \& Pittman, B. (2011). Engineering and innovation: An immersive start-up experience. Computer, (4), 38-46.

10. Weilerstein, P., \& Besterfield-Sacre, M., \& Golding, K., \& Shartrand, A. (2010, June), Technology Entrepreneurship Programs In U.S. Engineering Schools: An Analysis Of Programs At The Undergraduate Level Paper presented at 2010 Annual Conference \& Exposition, Louisville, Kentucky. https://peer.asee.org/16057 